North-Holland

\title{
UNION EFFECTS ON WAGES AND WAGE GROWTH
}

\author{
Solomon W. POLACHEK \\ State University of New York at Binghamton, Binghamton, NY 13901, USA \\ Phanindra V. WUNNAVA \\ Middlebury College, Middlebury, VT 05753, USA
}

Michael T. HUTCHINS

Salomon Brothers, New York, USA

Received 24 January 1986

Final version received 22 April 1986

\begin{abstract}
This paper employs a pooled cross-section time-series error-variance-components model applied to panel data to present new estimates of the impact of unions on earnings profiles. It avoids union-status measurement errors alluded to by Freeman (1984) contained in current panel estimates by limiting analysis to a set of one-time union status switches for which union status data could be sufficiently cross-checked. It avoids heterogeneity biases by comparing entire earnings profiles for given workers before and after their union status change. Finally, potential selectivity biases in using a non-random sample of only union switchers, is found not to plague the reported results.
\end{abstract}

\section{Introduction}

Probably the most studied aspect of unions in the economics literature today is the impact of unions on worker earnings [Lewis (1963,1983), Freeman-Medoff (1984), and Hirsch-Addison (1986)]. One approach that has gained wide attention is to use panel data for estimation. Panel data enables the researcher to avoid unmeasurable sample heterogeneity biases that plague past cross-sectional estimates by concentrating on changes in measured variables for given individuals, under the assumption that unmeasured variables remain constant over time. Recently, however, Freeman (1984) criticized this methodology on the grounds that errors of measurement, especially with regard to changes in union status, impart severe downward biases when estimating union effects.

This paper constitutes an alternative approach by using a pooled cross-section time-series error-variance-component technique applied to panel data of one-time union status switchers. ${ }^{1}$ This approach avoids measurement error by having a sufficient number of years so as to cross-chcck union status on an annual basis. It combats heterogeneity biases by comparing entire earnings profile for given individuals before and after their union status changes. Finally, by using a Heckman-type

1 To our knowledge, panel data for a sample of one-time switchers was first used by Polachek and McCutcheon (1983) to analyze the impact of unions on employment stability. Extensions and further elaboration of the techniques applied to the impact of unions on wages are given in Wunnava (1986). 
selectivity correction, it tests for selectivity biases that may be present when we concentrate on a sample solely of union switchers.

\section{Panel analysis of the effect of unions on wages}

Current studies utilize panel data to run fixed effect models. Such models [Brown (1980), Duncan (1979)] are comparable to running regressions with both the independent and dependent variables expressed in deviation form (that is, as $x_{i j}-\bar{x}_{i}$ where $\bar{x}_{i}=\sum_{j} x_{i j} / T$ and $T$ equals the number of time periods). For data with two time periods this amounts to considering each variable as a first difference. Here union effects on wages can be measured by computing $\partial \Delta \ln Y_{i t} / \partial \Delta U_{i t}$ when earnings are expressed as

$\Delta \ln Y_{i t}=a_{1} \Delta X_{i t}+b_{1} \Delta U_{i t}+b_{2}\left(\Delta X_{i t} \Delta U_{i t}\right)+\epsilon_{i t}$,

where $\Delta$ denotes the first difference operator; $X$ denotes a vector of individual attributes reflecting characteristics that affect earnings, and $U$ is a dummy variable indicating union membership. As indicated, Freeman (1984) emphasized that biases often result from errors emanating from improper reporting of an individual's annual union status. He illustrated how small reporting errors can lead to large errors in estimated union effects.

\section{The time-series wage equation adopted for panel data}

Our approach entails the application of error-variance component techniques to estimate an earnings function for a set of individuals from the University of Michigan Panel Study of Income Data (PSID) during the period 1968 to 1981. In the PSID, all data prior to 1968 are retrospective. All data following 1968 are current. Thus three life-cycle segments emerge: (1) schooling, (2) experience prior to 1968, and (3) post-1968 experience (measured as $t$ minus experience in 1968). An estimating equation can be derived from the standard earnings function,

$\ln Y_{i t}=a_{0}+a_{1} S_{i t}+a_{2} j_{i t}+a_{3} j_{i t}^{2}+a_{4} e_{i t}+a_{5} e_{i t}^{2}+\epsilon_{i t}$,

where $S$ equals years of schooling, $j$ experience prior to $1968, e$ experience since 1968 and the squared terms denote typical non-linearities inherent in earnings functions. The $a_{1}$ coefficient reflects returns from schooling, the pre-1968 experience coefficients reflect amounts of and returns from on-the-job training prior to 1968 , and the post-1968 coefficients reflect the same for investments after 1968. If unions affect earnings levels as well as investment (returns from seniority), then the earnings function (2) can be rewritten with a union dummy variable $(U)$, as well as the interaction of $U$ and each of the experience variables,

$$
\begin{aligned}
\ln Y_{i t}= & a_{0}+a_{1} S_{i t}+a_{2} j_{i t}+a_{3} j_{i t}^{2}+a_{4} e_{i t}+a_{5} e_{i t}+a_{6} U_{i t} \\
& +a_{7}\left(U_{i t} * e_{i t}\right)+a_{8}\left(U_{i t} * e_{i t}^{2}\right)+a_{9}\left(U_{i t} * j_{i t}\right)+a_{10}\left(U_{i t} * j_{i t}^{2}\right)+\epsilon_{i t} .
\end{aligned}
$$


Data on unionization are not available prior to $1968,{ }^{2}$ and hence are not contemporaneous with experience. Therefore, we omit the interaction terms between $j$ and unionization, thereby yielding

$\ln Y_{t t}=a_{0}+a_{1} S_{i t}+a_{2} j_{i t}+a_{3} j_{i t}^{2}+a_{4} e_{i t}+a_{5} e_{i t}^{2}+a_{6} U_{i t}+a_{7}\left(U_{i t} * e_{i t}\right)+a_{8}\left(U_{i t} * e_{i t}^{2}\right)+\epsilon_{i t}$.

Since in reality we estimate earnings functions before and after status changes, we need a sufficient number of pre- and post-switch data for each individual switcher. Hence we choose one-time switchers with at least four data points in each status state. Looking at one time switchers in this framework insures against erratic responses to the union membership question becausc, if data indicate a switch in any given year, then data for that individual would only be used if this union status change continued in each subsequent year. If the probability of a reporting error were $p$, then the probability that this error be perpetuated in $X$ succeeding periods is $P^{\bar{x}}$, a very small number, given that to begin with $p<1$.

In order to avoid the already mentioned heterogeneity biases, we estimate eq. (4), concentrating solely on one-time switchers. We look separately at union joiners and union leavers. Theory dictates that union joiners are most likely to be the able young workers, while union leavers arc probably less able involuntary leavers. In short, each group is completely different and potentially at opposite ends of the quality spectrum. By separately looking at the effects of unions on each of these diverse groups of workers, one can ascertain the similarity of estimated union effects. Given the diversity of the groups, similar parameters would imply the globility of these estimates. Differing parameter estimates would indicate the degree to which divergence exists in the union impact on wages. Still, given that switchers represent a select sample, we also estimated eq. (4) using an inverse Mills ratio so as to adjust for possible selectivity type biases.

The coefficients of the union as well as the post-union 1968 experience interaction terms give a measure of union impact. The union impact on wage level is equal to $\partial \ln y / \partial u=a_{6}+a_{7} e+a_{8} e^{2}$. The union impact on the age-earnings profile slope is $\partial^{2} \ln y / \partial U \partial e=a_{7}+2 a_{8} e$.

\section{The empirical model}

We estimate the earnings function (4) using 14 years of wage data. Pooling the data over both cross-section and time-series requires non-OLS estimation procedures because of potential correlation among the disturbances. The standard error components model attempts to account for these correlations, raising the asymptotic efficiency of the estimates. This is done by breaking the usual error term into three separate components, an individual component, a time component, and a component accounting for the possibility that disturbances may be peculiar to an individual at a specific point of time. When adding the new stochastic error term, $E_{i l}$, to (4), the wage function takes the form

$$
\begin{aligned}
w_{i t} & =a_{0}+a_{1} S_{i t}+a_{2} j_{i t}+a_{3} j_{i t}^{\overline{2}}+a_{4} e_{i t}+a_{5} e_{i t}^{\hat{2}}+a_{6} U_{i t}+a_{7}\left(U_{i t} * e_{i t}\right)+a_{8}\left(U_{i t} * e^{2}\right)_{i t}+E_{i t}, \\
i & =1, \ldots, N, \quad t=1, \ldots, T
\end{aligned}
$$

where $w_{i t}$ is the natural logarithm of real hourly wages (in 1968 dollars) of the $i$ th individual in the

2 Union membership for 1973 was extrapolated since it was not reported in the PSID. 
$t$ th year. An inverse-Mills ratio term is added to test for possible selectivity biases. As mentioned above, the error structure is assumed to be of the form

$E_{i t}=v_{i}+e_{t}+z_{i t}$,

where $v_{i}$ is a random individual component, $e_{t}$ is a random time component, and $z_{i t}$ is a purely random component. The variants $v_{i}, e_{r}, z_{i t}$ are assumed to be independent of each other as well as independent of the $X_{i t}$ 's. They are also assumed to be identically distributed with means of zero and variances $\sigma_{v}^{2}, \sigma_{v}^{2}$ and $\sigma_{z}^{2}$, respectively. ${ }^{3}$

\section{Estimates}

Modified-generalized-least-squares (MGLS) wage equations are estimated in table 1. The human capital type coefficients are comparable to those obtained elsewhere. The earnings profile is concave in experience and tenure, and the schooling coefficients are reasonable and statistically significant. In addition, the union and union-experience interaction terms are jointly significant. The inverse-Mills ratio, however, was statistically insignificant, implying that possible selectivity biases of using a limited sample of switchers are insignificant. ${ }^{4}$

\subsection{The union effect on wages}

The direct wage effects of changing union status is obtained by evaluating $\partial \ln w / \partial U$ at the year when the union status switch occurs [columns (1) and (3)]. It appears that these are different for joiners and leavers. To a certain extent this is true. Joiners gain $9.0 \%$ immediately upon joining, while leavers face a $21.6 \%$ loss (thereby implying a $21.6 \%$ union effect) immediately upon leaving. ${ }^{5}$ However, the extent of these differences are exaggerated in the data. Most union status changes are accompanied by a change in employment status as well. Theories of specific training imply that employment turnover usually results in an initial loss in earnings power because of lost job-related human capital. Involuntary turnover accentuates this earnings loss. By accounting for these job turnover effects, one can reduce the degree of measured differences in the status coefficients.

Columns (2), (4), (5) and (6) contain panel earnings regression estimates but with an emphasis on job change (the $E$-variable). Four strata of job changers are considered: (1) union joiners, (2) union leavers, (3) those always in a union over the 14-year period, and (4) those never in the union. For each stratum the effect of employment change is computed as $\left.(\partial \ln w /$ demployment $\Delta)\right|_{e=s w i t c h}$. The

3 The best linear unbiased estimate for the coefficient vector $a=\left(a_{0}, a_{1}, a_{2}, \ldots, a_{8}\right)$ when the variance components are known is the generalized least square estimates $\hat{a}=\left(X^{11} U^{-1} X\right)^{-1} X^{\prime \prime} U^{-1} w$. When the variance components are unknown, the GLS estimates cannot be computed. Instead, the modified (feasible) GLS estimate is used. The variance components of $E$ are estimated by the 'fitting-of-constant' method of Searle (1971). The estimate of $(a)$ using the estimated covariance matrix possesses the desireable properties of consistency and asymptotic efficiency.

4 Because of space limitations, we do not present the results containing the inverse-Mills ratio. They are available upon request.

5 For joiners,

$\left.(\partial \ln w / \partial U)\right|_{\text {swicth }=5.8}=-0.159+0.072(5.8)-0.005(5.8)^{2}=0.0906($ gain $)$,

while for leavers,

$\left.(\partial \ln w / \partial U)\right|_{\text {switch }=5.8}=0.0025+0.045(5.8)-0.0014(5.8)^{2}=0.216(\operatorname{loss})$. 
Table 1

MGLS estimates of union status and employment change on wages ( $t$-values in parentheses). ${ }^{a}$

\begin{tabular}{|c|c|c|c|c|c|c|}
\hline & \multicolumn{2}{|c|}{ Joiners $(N=30)$} & \multicolumn{2}{|c|}{ Leavers $(N=63)$} & \multicolumn{2}{|c|}{ Employment change } \\
\hline & $\begin{array}{l}\text { Union status } \\
\text { change } \\
\text { (1) }\end{array}$ & $\begin{array}{l}\text { Employment } \\
\text { change } \\
(2)\end{array}$ & $\begin{array}{l}\text { Union status } \\
\text { change } \\
\text { (3) }\end{array}$ & $\begin{array}{l}\text { Employment } \\
\text { change } \\
\text { (4) }\end{array}$ & $\begin{array}{l}\text { Always union } \\
\text { (5) }\end{array}$ & $\begin{array}{l}\text { Never union } \\
(6)\end{array}$ \\
\hline Intercept & $\begin{array}{r}4.67 \\
(35.0)\end{array}$ & $\begin{array}{r}4.65 \\
(34.6)\end{array}$ & $\begin{array}{r}5.06 \\
(29.1)\end{array}$ & $\begin{array}{c}5.3 \\
(36.8)\end{array}$ & $\begin{array}{c}5.4 \\
(76.5)\end{array}$ & $\begin{array}{r}4.11 \\
(80.6)\end{array}$ \\
\hline$S$ & $\begin{array}{l}0.065 \\
(9.1)\end{array}$ & $\begin{array}{l}0.065 \\
(9.2)\end{array}$ & $\begin{array}{l}0.045 \\
(5.3)\end{array}$ & $\begin{array}{l}0.031 \\
(3.7)\end{array}$ & $\begin{array}{l}0.031 \\
(8.3)\end{array}$ & $\begin{array}{r}0.10 \\
(39.0)\end{array}$ \\
\hline$j$ & $\begin{array}{l}0.021 \\
(3.1)\end{array}$ & $\begin{array}{l}0.021 \\
(3.0)\end{array}$ & $\begin{array}{l}0.016 \\
(3.5)\end{array}$ & $\begin{array}{r}0.02 \\
(3.9)\end{array}$ & $\begin{array}{l}0.008 \\
(2.6)\end{array}$ & $\begin{array}{r}0.04 \\
(22.3)\end{array}$ \\
\hline$j^{2}$ & $\begin{array}{c}-0.004 \\
(2.7)\end{array}$ & $\begin{array}{c}-0.0004 \\
(2.7)\end{array}$ & $\begin{array}{c}-0.0004 \\
(3.5)\end{array}$ & $\begin{array}{c}-0.0004 \\
(3.6)\end{array}$ & $\begin{array}{l}-0.00007 \\
(0.9)\end{array}$ & $\begin{array}{l}-0.00008 \\
(20.7)\end{array}$ \\
\hline$e$ & $\begin{array}{l}0.034 \\
(1.0)\end{array}$ & $\begin{array}{l}0.068 \\
(3.1)\end{array}$ & $\begin{array}{r}0.008 \\
(0.03)\end{array}$ & $\begin{array}{r}0.01 \\
(0.6)\end{array}$ & $\begin{array}{r}0.04 \\
(3.9)\end{array}$ & $\begin{array}{l}0.028 \\
(3.5)\end{array}$ \\
\hline$e^{2}$ & $\begin{array}{l}0.00005 \\
(0.02)\end{array}$ & $\begin{array}{r}-0.003 \\
(2.55)\end{array}$ & $\begin{array}{c}-0.0011 \\
(0.7)\end{array}$ & $\begin{array}{c}-0.002 \\
(1.7)\end{array}$ & $\begin{array}{c}-0.002 \\
(3.3)\end{array}$ & $\begin{array}{c}-0.0017 \\
(3.3)\end{array}$ \\
\hline$U$ & $\begin{array}{c}-0.159 \\
(1.0)\end{array}$ & & $\begin{array}{l}0.0025 \\
(0.01)\end{array}$ & & & \\
\hline$U * e$ & $\begin{array}{l}0.072 \\
(1.5)\end{array}$ & & $\begin{array}{l}0.045 \\
(1.2)\end{array}$ & & & \\
\hline$U * e^{2}$ & $\begin{array}{c}-0.005 \\
(1.7)\end{array}$ & & $\begin{array}{l}-0.0014 \\
(0.5)\end{array}$ & & & \\
\hline$E$ & & $\begin{array}{c}-0.108 \\
(1.2)\end{array}$ & & $\begin{array}{l}-0.226 \\
(2.7)\end{array}$ & $\begin{array}{r}-0.03 \\
(0.6)\end{array}$ & $\begin{array}{c}-0.146 \\
(3.8)\end{array}$ \\
\hline$E * e$ & & $\begin{array}{l}0.009 \\
(0.8)\end{array}$ & & $\begin{array}{c}0.02 \\
(2.0)\end{array}$ & $\begin{array}{l}0.0073 \\
(1.2)\end{array}$ & $\begin{array}{l}0.012 \\
(2.6)\end{array}$ \\
\hline$R^{2}$ & 0.273 & 0.269 & 0.135 & 0.085 & 0.155 & 0.241 \\
\hline $\begin{array}{l}D . F . \\
F \text {-Ratio }\end{array}$ & $\begin{array}{l}411 \\
19.3\end{array}$ & $\begin{array}{l}412 \\
21.7\end{array}$ & 873 & $\begin{array}{l}804 \\
107\end{array}$ & 1462 & $\begin{array}{l}6726 \\
3060\end{array}$ \\
\hline $\begin{array}{l}\text { Variable definit } \\
\begin{aligned} S= & \text { Highest gr } \\
& \text { completed } \\
& \text { in } 1968\end{aligned}\end{array}$ & $\begin{array}{l}\text { itions and mean } \\
\text { rade } \\
11.7\end{array}$ & & 11.4 & & 11.03 & 13.54 \\
\hline $\begin{aligned} & j= \text { Expr. in } \\
& 1968 \text { (age - } \\
&5-8)\end{aligned}$ & - & & 20.2 & & 20.77 & 17.73 \\
\hline $\begin{aligned} e= & \text { Expr. at } \\
& \text { switch } \\
& \text { since } 1968\end{aligned}$ & $\begin{array}{l}5.86 \\
7.5\end{array}$ & & $\begin{array}{l}5.83 \\
7.5\end{array}$ & & - & $\overline{7}-\overline{ }$ \\
\hline
\end{tabular}

a $U$ equals 1 if union. $E$ equals 1 if employment change. 
results indicate between a $6 \%$ and $11 \%$ loss for joiners and leavers, a $7.6 \%$ loss in earnings for the non-union group, and a $1.0 \%$ gain for union members. ${ }^{6}$ Therefore, the above computation of the union effect is underestimated for joiners and overestimated for leavers. Recomputation of the union effect after adjusting for job change yields a 10.6\% to 15\% union impact (when the leaver and joiner employment-change wage equations are used) and a $16.6 \%$ to $22.6 \%$ union impact (when the union and non-union employment-change wage equations are used). ${ }^{7}$ These estimates fall between current panel and cross-sectional measures of union effects, and this is perfectly reasonable especially given Freeman's (1984) claim that the true union effect lies between tradition panel and cross-sectional estimates.

\subsection{A heterogeneity-free estimate of the effect of unions on the slope of the age-earnings profile}

Both joiner and leaver regressions indicate that unions do not flatten the age-earnings profile. A positive or a zero estimate of the derivative $\partial^{2} \ln w / \partial e \partial u$ evaluated at the switch point casts serious doubt on the validity of the hypothesis that unions flatten profiles. For union joiners there is a $1.4 \%$ increase ${ }^{8}$ in the life-cycle earnings profile from joining a union. For the set of union leavers, we find a similar result. Leavers had a $2.8 \%$ decrease $^{y}$ in the age-earnings profile from leaving the union. Since none of these estimates are significantly negative, a conclusion that unions do not flatten age-earnings profiles is justified. This is consistent both with unions organizing where the age-earnings profile is flat [Polachek (1982)], and with cross-sectional age-earnings profiles being flatter in unionized firms [I azear (1983)], but inconsistent with the inference that unions flatten age-earnings profiles, as is often currently hypothesized.

\section{References}

Brown, C., 1980, Equalizing differences in the labor market, Quarterly Journal of Economics 94, Feb., 113-133.

Duncan, G., 1979, An empirical model of wage growth, in: G. Duncan and J. Morgan, eds., Five thousand American families, Vol. VII (Institute for Social Research, Ann Arbor, MI).

Freeman, R., 1984, Longitudinal analyses of the effects of trade unions, Journal of Labour Economics 2, no. 1, Jan., 1-26. Freeman, R. and J. Medoff, 1984, What do unions do? (Basic Books, New York).

Hirsch, B. and J. Addison, 1986, The economic analysis of unions: New approaches and evidence (Allen and Unwin, London).

Lazear, E., 1983, A competitive theory of monopoly unionism, American Economic Review 73, Sept., 631-643.

Lewis, G., 1963, Unionism and relative wages in the United States (University of Chicago Press, Chicago. IL).

Lewis, G., 1983, Union relative wage effects: A survey, chs. 5 and 7, Presented at a conference on the economics of trade unions (NBER, Cambridge, MA).

Polachek, S., 1982, The unionization of white collar workers, Mimeo.

${ }^{6}$ These results computed as follows:

Joiners: $\left.(\partial \ln w / \partial E M P)\right|_{\text {at switch }-5.8}=-0.108+0.009(5.8)=-0.0558=-0.06$,

Leavers: $\left.(\partial \ln w / \partial E M P)\right|_{\text {at switch }-5.8}=-0.226+0.02(5.8)=-0.11$

Always union $:\left.(\partial \ln w / \partial E M P)\right|_{\text {at switch }=5.8}=-0.03+0.0073(5.8)=0.012=0.01$,

Always non-union: $\left.(\partial \ln w / \partial E M P)\right|_{\text {at switch }=5.8}=0.0146+0.012(5.8)=-0.076$.

support the contention that union members accumulate less specific training than non-union workers, but that union leavers are involuntary job changers.

7 These results are computed as: $0.09+0.076=0.166$, and $0.216+0.01=0.226$.

$\left.{ }^{8}\left(\partial^{2} \ln w / \partial U \partial e\right)\right|_{\text {at switch }}=0.072-2(0.005)(5.8)=0.014$.

$\left.{ }^{9}(\partial \ln w / \partial U \partial e)\right|_{\text {at switch }}=0.045-2(0.0014)(5.8)=0.028$. 
Polachek, S. and E. McCutcheon, 1983, Union effects on employment stability: New estimates using panel data, Journal of Labor Research 4, Summer, 273-287.

Scarle, S., 1971, Topics in variance component estimation, Biometrics 27, 176.

Wunnava, P., 1986, The effect of unions on the level and slope of the age-earnings profile in a life cycle framework: Evidence from panel data, Ph.D. dissertation (State University of New York at Binghamton, Binghamton, NY). 